\title{
INCULCATING TOLERANCE BY MULTICULTURAL BASED PPKN LEARNING
}

Gunartati, Zamroni, Abdul Gafur

STKIP Catur Sakti BantulPPS, Universitas Negeri Yogyakarta tatiknurwangi@gmail.com

\begin{abstract}
This study aims to: (1) describe the teaching conditions of multicultural-based PPKn implemented by SMA in DIY, (2) produce a feasible model of teaching PPKn based on multiculture for inculcating tolerance for senior high school students, (3) find out the effectiveness of developed teaching model. This research was research and development adopting the procedural model of Borg \& Gall. The procedures were divided into four phases, namely: (1) the needs analysis phase (2) the development stage of models and expert judgment (3) testing and refining the model, and (4) dissemination phase. The experiment was conducted at SMA Jetis, SMA 2 Bantul, and SMA 2 Wates. The Subjects were teachers and students of XI class of those SMAs. The data analysis used the descriptive analysis and t-test to determine the effectiveness of the product. The results of the reaseach are as follow. First, the teaching of PPKn in SMA in DIY is still conventional and not yet exploring multicultural values. Second, teaching model of multiculturalbased PPKn declared eligible by material experts, instructional experts and assessment of the teachers. And the third, the teaching model developed is effectively used in the teaching and learning. This is indicated by the significant differences in learning outcomes between the experimental and control groups. The effectiveness is proved by using $t$ test that the result is significant $(p<0.05)$, and the mean of experiment group is higher than the mean of the control group.
\end{abstract}

Keywords: teaching, PPKn, multicultural, tolerance. 


\section{INTRODUCTION}

There is no one who wants a chaotic life only due to our different reasons in terms of ethnicity, language, faith, habit, food and others. Therefore, we need to fertilize tolerance in societal, national and state life. Accordingly, it is urgent to adopt theme associated with efforts to deal with the difference through Multicultural Based PPKn Teaching organization.

Western cultural experts, in early $20^{\text {th }}$ century began to think of way to avoid ethnocentrism concept in multicultural society as result of various more complex cultural disputes. One way used is to give conception called as Cultural Relativity. In this conception, no culture is higher and better and no culture is lower and worse. It means that we must give equal respect to all varying traditions found in our society. Thus, evaluation may not be based on individual experience with measure of culture alone.

Development of attitude and behavior respecting and appreciating other different individuals and groups early is to reduce possible social conflicts. If there is assumption that various social conflicts are caused by lower conception and appreciation for other national/ethnic cultures, one effort to cope with is to educate individuals in order that they understand and appreciate the cultural difference. Through education, we can create individuals who do not isolated by narrow missing perspective. One of solutions to it is Multicultural Based PPKn Teaching. This teaching should be implemented systematically, integrally and sustainable.

Multicultural Based PPKn Teaching tries make students able to develop respect to individuals with different tradition and culture, give chance to work together with individuals or groups of people with different races directly. Thos teaching also helps students recognize requirements of varying cultural views, socialize students that value conflicts frequently become cause of conflicts between groups, help students develop their cultural inheritances, etc. Some usable strategies to develop Multicultural Based PPKn Teaching are Cooperative Learning, namely strategies of Cooperative Learning activities, integrated with Concept Attainment strategy., Value Analysis strategy, and Social Investigation strategy. The strategies can be implementable coincidently and imaginable in steps of Multicultural Based PPKn Teaching model.

Multicultural Based PPKn Teaching recognizes, accepts and confirms differences and similarities of human associated with gender, race, and class (Sleeter \& Grant, 1998). This teaching also develops an attitude in viewing human uniqueness without discriminating race, culture, gender, sex, body condition or economic status of an individual (Skeel, 1995). As a part of multicultural education, , it must prioritize educational strategy using variety of cultural backgrounds of students as one of forces to establish multicultural attitude. This strategy is very useful, at least for schools as educational institutions to form collective conception on cultural concept, cultural difference, balance, and democracy in wide meaning (Liliweri, 2005). Multicultural education is defined as a social policy based on principles of cultural maintenance and mutually having respect between cultural groups in a society. Multicultural teaching is basically a national education program in order that multicultural community can participate in realizing ideal democratic life for their nation (Banks, 1993).

In wide context, multicultural education tries to help integrate nation democratically, emphasizing in perspective of community plurality in various nations, ethnics, different cultural groups. Thus schools are conditioned to reflect practice of democratic values. Curriculum shoes various different cultural groups in community, language, and dialect, where students more widely speak of respect feeling between them and appreciate cooperative values highly than speak of competition and prejudices between different students in relation to race, ethnic, culture and social status groups.

As Multicultural Based Teaching, it must be based on philosophical idea on freedom, justice, equality and protection of human rights Essence of multicultural education prepares all students to work actively leading to structural equality in school institution and organization. Multicultural education is not a policy leading to inclusive teaching and educational institutions and teaching by pluralism propaganda via curriculum playing a role in cultural competition of individuals. 
Multicultural Based Ppkn Teaching tries to empower students to develop respect to individuals with different cultures, give chance to work together with individuals or groups of individuals with different ethnics or races directly. Type of this teaching also helps students recognize requirements of varying cultural views in developing pride for their cultural inheritance, making students aware that conflict of values between societal groups (Savage \& Armstrong, 1996). The Multicultural Based Ppkn Teaching is coordinated in making efforts to develop compeency of students in viewing life of various different cultural perspectives from their own cultures, and positive attitude to differences of cultures, races and ethnics (Farris \& Cooper, 1994).

Objectives of Multicultural Based Teaching can be identified as follows: (1) to function as school role in viewing varying students; (2) to help students develop positive treatment to cultural, race, ethnical, and religious differences of groups; (3) to give students' tenacity by teaching them to take decision and social skill; (4) to help students build cross-cultural dependency and give positive conception to the, concerning differences of groups (Banks in Skeel, 1995).

In addition, the Multicultural Based Teaching is developed based on educational concept for freedom (Dickerson, 1993; Banks $\&$ Ambrose, 1995) aiming at: (1) helping students develop knowledge, attitude and skill to participate in democracy freedom of community; (2) improving freedom, competency, skill for cultural and ethnical cross-borders to participate in some other cultural groups and individuals.

Characteristics of Multicultural Based Ppkn Teaching are as follows:

1. Teacher must plan teaching strategy usable in class.

2. Multicultural teaching taught in classroom can be begun from small things, but the things are full of significances. For example, in initial learning, teacher must self-introduce to students, vice versa; and each mentions cultural identity; in star and end learning hours, teacher begins to instruct students to prepare class using certain local language; teacher can instruct students having minority religion to lead pray.
3. Teacher can give tasks to students divided into some groups. Division of groups considers multi-cultures of students. In one of groups consisting of students with cultural differences, in order that there is interaction between individuals with horizontally background differences.

4. Teacher includes load of multicultural education in relevant discussion materials.

\section{Definition of Tolerance}

Tolerance must be based on broad minded attitude to others considering self-held principles. Occurring and valid tolerance due to different principles, and respect differences or principles of other individuals without sacrificing principles alone. In other words, implementation is limited to detailed and technical aspects, not in principal issue. $16^{\text {th }}$ November is day of International Tolerance Celebration, adopted by UNESCO from Declaration of Principles on Tolerance, on $16^{\text {th }}$ November 1995.

According to term tolerance, it means to respect, allow, let establishment of opinion, view, belief, habit, conduct and others or contrary to their own conviction. For example, religion, ideology, race (Poerwadarminta, 1999). Whereas, as suggested by Tillman, tolerance is a method to reach peace. Tolerance is called as essential factor for peace (Tillman, 2004, p. 95). Principally, tolerance means characteristics and attitudes to respect. Characteristics and attitudes to respect must be show by everyone for plural forms in Indonesia. Because tolerance is simplest attitude, but it has positive impact on national integrity in general and societal harmony in particular. Absence of tolerant attitude can trigger unexpected conflicts. Implementation of this tolerant attitude must be based on broad minded attitude to others considering self-held principles, namely without sacrificing the principles (Daud Ali, 1989:83). It is clear that tolerance occurs and applies because there are different principles and respects differences or principles of others without sacrificing principles alone. In using this tolerance, there are two interpretation of the concept. First, negative interpretation stating that the tolerance is sufficiently to require attitude to let and not inflict other different or same individuals or groups. Second, positive interpretation stating 
that tolerance is not like the first (negative interpretation), but also it must have support and assistance of other individuals or groups (Abdullah, 2001, p. 13).

Tolerance has the following points of reflection: (a) peace is target, tolerance is method; (b) tolerance is open and receptive in beauty of differences; (c) tolerance appreciates individuals and their differences, eliminates mask and stress caused by ignorance. It gives chance to find and eliminate stigma caused nationality, religion and what are inherited; (d) tolerance is mutually appreciating one and other through notion; (e) seed of intolerance is fear and ignorance; (f) seed of tolerance is love, watered by affection and maintenance; $(\mathrm{g})$ if there is no love, there is no tolerance; (h) one understands goodness in other individuals and situation has tolerance; (i) tolerance also means competency to face difficult situation; (j) tolerance to unsafe life letting pass, light, ignoring others are light; (k) in notion and open thought of tolerant individuals, it means treating others differently, and shows tolerance. Finally, good relation develops (Tillman, 2004, p. 94).

So, it is concluded that tolerance is one's attitude where he/she is competent to let in broad mind, respect, recognize, respect and not resent, understand, open to opinion, differences, view, belief, habit, attitude and others or contrary to one's self conviction.

\section{Elements of Tolerance}

Tolerance has elements which must be emphasized in expressing other individuals. The elements are:

a) Give freedom and independence;

Each human is given freedom to do, move, and desire according to self and also in choosing religion or faith. This freedom is given from human birth to death and freedom or independence human chooses cannot be replaced or called by others in any way, because the freedom is coming from the One God, where the freedom must be kept and protected. Each state protects freedoms of each human in both available Law and regulation (Abdullah, 2001, p. 202).

b) Recognize Rights of Everyone's mental attitude recognizing rights of each individual in determining conduct and fate of each individual. Certainly, implementable attitude or behavior does not violate rights of other individuals because, if it is so, life of community will be chaotic.

c) Respect other' faith.

In this context, it is applicable to tolerance between religions. However, if it is associated with social tolerance, it is to respect other's faith in choosing a group. For example, in decision making, one chooses self-defense organization. As a tolerant individual, one must respect other's decision different from group's decision in our self-defense organization.

d) Mutually understand. There will be no mutual respect between peers if they have no mutual understanding. Mutual anti and hate, mutual compete for effect is one result of no mutual understanding and respecting between one and other (Hasyim, 1979, p. 23).

\section{METHODS}

This study used two qualitative and quantitative approaches with research and development $(\mathrm{R} \& \mathrm{D})$. this study was conducted in four following stages: (1) need assessment through study of literatures and field/empiric study; (2) development of model and expert judgment; (3) trial and error as well as improvement of model; and (4) dissemination.

Three locations in Yogyakarta were determined by purposive sampling. Types of data are primary and secondary data. Respondents and key informant of this study are teachers, students, headmaster and figures giving information on researched problems. Data were collected by interview, observation, documentation, and questionnaires. The data were analyzed descriptively and quantitatively and using t-test and F-test using SPSS software.

In relation to qualitative data, criteria of data were legalized by seeing credibility through source and method triangulation technique, extension of researcher attendance, checking of associates and diligence of observation, transferability, dependability and confirm-ability; whereas quantitative data were processed by content validity test with Spearman correlation using Alpha Cronbach model. 


\section{RESULTS AND DISCUSSION}

Results of finding in field indicate that students' attitude to PPKn so far tends to belittle. Most of them view partially PPKn lesson, this lesson is found not so important. Teaching model and method of PPKn teacher tended to be monotonous, instruments and infrastructures of teaching are also limited teaching widely focused on aspect of knowledge. Even, in some schools, this lesson is held by teacher with basic education and not PPKn. PPKn teaching in Senior High School experienced problems such as teaching dominated by cognitive domain and conventional characteristics (Trisiana, 2016, p. 266). Students are clever to memorize concepts, facts and events, but these are insignificant in real life, so that a model is necessary for innovative learning making students able to dig, formulate, describe and analyze as well as implement knowledge and values in daily life; therefore, it is necessary to make efforts to develop teaching model not dominant in cognitive aspect but also touching affective aspect and psychomotor aspect.

Relevant teaching process considering characteristics of Senior High School students from physical, moral, social, cultural, emotional and intellectual aspects consists the following knowledge domains: (1) making planning design by identifying RPP compilation signs; (2) identifying SKL, KI, and KD made in RPP; (3) making performance design; (4) assessment designing; (5) identifying norms of authentic assessment designing in learning process and results; (6) identifying types and forms of assessment in process and learning results according to lesson characteristics; (7) making model guidance book of Multicultural Based Ppkn Teaching, harmonized with 2013 curriculum, which will be followed up by students and teacher book making.

All results of product specification support 2013 curriculum in Multicultural Based Ppkn Teaching, and implementation of teaching process optimally possible, and instructional impact and accompanying impact. Instructional impact is results of learning achieved or associated with learning materials directly, whereas accompanying impact is results of learning achieved as result of use of Multicultural Based Ppkn Teaching model. In this study, accompanying impact leads to development of core competency, showing attitude to appreciate multicultural values which are competencies to accept, implement, appreciate and understand multicultural values and self place as citizen aware of rights and duties.

As discussion of results of model effectiveness test developed in this study, we can mention the following:

Multicultural education needs to integrate in various life aspects, including life in school setting. Therefore, school must be vehicle to create conductive situation in giving comprehensive understanding on multicultural education.

Model of Multicultural Based Ppkn Teaching, if associated with multicultural education, has not been optimal yet in reaching expected target. At least there are three reasons why teacher must be able to develop learning model. First, there is no model before second, there has been a model before, but the model has not functioned maximally; third, as variation of model existing before.

Indicator of PPKn learning success is participation of citizens in relation to achievement of citizens' skill not separated from civic knowledge, civic skill and civic disposition.

Development of Multicultural Based Ppkn Teaching model will help achieve desirable target in PPKn, for example, how civic value will be internalized effectively until cognitive, affective and psychomotor levels. Model developed in this study will also reinforce implementation of 2013 curriculum implicitly also emphasizing on multicultural education.

Results of effectiveness test of Multicultural Based Ppkn Teaching model using $t$ test indicate that $\mathrm{P}<0.05$, so that there is significant difference between conventional learning model and learning model developed in thus study.

Model developed in this study is consistent with personal model group as presented by Joyce, Weil, \& Calhoun (2016, p. 445) suggesting that personal model is widely emphasized on formation and organizing of life reality. Personal teaching model can guide students to healthier emotion and mentality developing self-confidence and realistic feeling, and through development of tolerant attitude to others. In this model, it is expected 
that teaching-learning process can help students develop productive relation alone to multicultural setting.

Multicultural education has strategic values in education. Without education focusing on multicultural perspective development in life, it is impossible to create presence of various cultures in future in Indonesia community. The importance of multicultural education is caused by the following: first, religion, ethnicity and tradition, it is actually a most important bond in Indonesian students' life as a nation. However, it will destroy harmonic community force when it is used as political weapon or facility for economic individuals and groups. In this case, religion is associated with ethnic or life tradition of a community. Each of individuals has used religious principles to guide them in life in community, but not various notions of religious faith on the other hand. It can only be conducted through multicultural education to achieve religion. Second, faith is an important element in life together. Plural community always thinks of risk for various differences. Appearance of risk from suspect/fear or unbelief in others can also occur when there is no communication in plural community. Third, tolerance is a highest form, indicating that we can achieve faith. Tolerance can be reality when we assume presence of differences. Faith is an issue which can be changed. Therefore, tolerance has no need to always keep faith. To achieve target as democratic Indonesian human and can live in Indonesia, multicultural education is necessary.

\section{CONCLUSIONS AND TARGETS}

\section{Conclusions}

Approach to multicultural education and tolerance applied by teacher to PPKn learning given to different students culturally motivates and lead students to have positive feeling, develop self-concept, improve tolerance and will receive others. Teacher makes effort to create a learning arena in cultural group.

Multicultural Based Ppkn Teaching is conducted as efforts to motivate social structure similarity and cultural tolerance with power distribution between groups. This learning is effort for social reconstruction in order that there are social structure similarity and cultural tolerance where objective is to prepare each of active students to make social structure similarity.

Multicultural education becomes our responsibility together, not only in school scope but also in home and social scope with inculcation in our students and children' mind, suggesting that differences are a life reality which must be experienced, all have regulator, so that it is improper we avoid responsibility. Let's improve and develop multicultural education and tolerance in PPKn learning organization.

\section{Recommendations}

Management of multicultural education should be conducted systematically, structurally and measured at result level. It should be based on standards already determined and agreed together between government and stakeholders. Thus, this Multicultural Based Teaching will give strong bases to students to believe, perceive and evaluate as well as take rational actions for available cultural problems.

\section{REFERENCES}

Abdullah. (2001). Pluralisme agama dan kerukunan dalam keragaman. Jakarta: Kompas.

Banks, J. A. (1993). Approches to multicultural curriculum reform. In J. A. Banks \& C. Banks (Eds.), Multicultural education: issues and perspektives. Boston: Allyn \& Bacon.

Banks, J. A., \& Ambrose, A. C. (1995). Teaching strategies for the social studies. New York: Longman, Inc.

Dickerson, S. (1993). Multiethnic education. Boston: Allyn \& Bacon.

Farris, P. J., \& Cooper, S. M. (1994). Elementary social studies: A whole languages approach. Iowa Brown \& Benchmark Publisher.

Hasyim, U. (1979). Toleransi dan kemerdekaan beragama dalam Islam sebagai dialog \& kerukunan antarumat beragama. Surabaya: PT Bina Ilmu Offset. 
Joyce, B., Weil, M., \& Calhoun, E. (2016). Models of teaching (Alih Bahasa: Rianayati Kusmini Pancasari). Yogyakarta: Pustaka Pelajar.

Liliweri, A. (2005). Prasangka \& konflik: komunikasi lintas budaya masyarakat multikultural. Yogyakarta: LkiS.

Poerwadarminta. (1999). Kamus umum bahasa indonesia. Jakarta: Balai Pustaka.

Savage, T. V, \& Armstrong, D. G. (1996). Effective teaching in social studies (3rd ed.). New Jersey: Prenticec Hall. Inc. and Simon \& Schuster Company.

Skeel, D. J. (1995). Elementary social studies: challenges for tomorrow's world orlando. Florida: Harcourt Brace \& Company.

Sleeter, C. E., \& Grant, C. A. (1998). Making Choices for multicultural education: Five aproaches to race, class and gender. Englewood cliffs, $\mathrm{Nj}$ : Prentice Hall.

Tillman, D. (2004). Pendidikan nilai untuk kaum muda dewasa (Terjemahan Risa Pratomo). Jakarta: Grasindo.

Trisiana, A. (2016). Pengembangan model pembelajaran project citizen untuk pendidikan karakter di SMA kota Surakarta. Disertasi. Universiyas Sebelas Maret. 